\title{
Designing Manufacturing Networks - An Empirical Study
}

\author{
Andreas Feldmann, Jan Olhager and Fredrik Persson \\ Linköping University, Department of Management and Engineering, \\ SE-58183 Linköping, Sweden \\ andreas.feldmann@1iu.se, jan.olhager@liu.se, fredrik.persson@liu.se \\ www.liu.se
}

\begin{abstract}
The design of the manufacturing network for a firm is an important factor for its competitive position. By manufacturing network we mean the plant or plants of the manufacturing firm and the relationships with external suppliers. The way that these operate together is central to the entire supply system supports the competition of the products in the marketplace. The decisions are typically categorised as related to facilities and vertical integration, two decision categories in an operations strategy. This paper presents the results of a survey of 84 Swedish manufacturing plants. The results show that competitive priorities such as quality and price play different roles in the networks, and that there is a significant difference in terms of how internal and external suppliers are selected.
\end{abstract}

\section{Keywords}

Empirical analysis, External suppliers, Internal suppliers, Manufacturing networks, Market characteristics, Survey research.

\section{Introduction}

The competitive positions of manufacturing firms stem from the design of the entire manufacturing network that needs to be in alignment with the market opportunities. The literature contains few models that help managers to design and manage plant networks. Colotla et al. [1] and Shi and Gregory [2] view a manufacturing network as a factory network with matrix connections, where each node (i.e. plant) affects the other nodes and hence cannot be managed in isolation. Rudberg and Olhager [3] analyze manufacturing networks and supply chains from an operations strategy perspective. They relate the manufacturing network to the decision categories of vertical integration and facilities, concerning both configuration and coordination. 
The issues of configuration and coordination dominate the research agenda on manufacturing networks. The former has its origins in the multi-plant research, and location-based criteria dominate (see e.g. DeBois et al. [4] and Ferdows [5,6]). The latter is mainly concerned with technology transfer and diffusion, as well as withinnetwork learning (see e.g. Gailbraith [7] and Flaherty [8]). However, in some instances attempts have been made to integrate the two issues to get an overall view of the manufacturing network (see e.g. Shi and Gregory [2] and Porter [9]).

This paper is based on a mail questionnaire survey to Swedish manufacturing firms, in order to capture the plant level perspectives of designing manufacturing networks in Swedish manufacturing firms. 500 manufacturing firms were contacted in January 2007. 84 useable responses were received, with a response rate of 16.8 percent. The survey is carried out at the plant level, providing the plant perspective of the manufacturing network. We report on the link to environmental factors such as market and product characteristics, including qualifiers and order winners. We explicitly treat the role and design of plants in the network and the principles for network design, including the reasons for location. We distinguish between internal and external suppliers and study the reasons for selecting a specific type of supplier. Using the survey data this paper gives an overview of the issues of importance for manufacturing network design in Swedish manufacturing firms. This is to our knowledge the first large scale empirical study on manufacturing network design.

In this paper we first present the research methodology. Then, we present and discuss the results concerning the market, plant, and supply characteristics.

\section{Research Methodology}

The questionnaire was designed with respect to the guidelines and recommendations presented in Dillman [10] and Forza [11]. As noted in [11] it is not possible for a company or a plant itself to answer any questions, this has to be done by human respondents. Therefore, people working with manufacturing and logistics in manufacturing companies were contacted and asked to respond in the survey. The respondents were all upper level managers related to production or logistics, and thus expectedly knowledgeable about the survey questions. The largest group of respondents was logistics/supply chain managers (32.6 percent of the responses), followed by production managers (30.1 percent), plant managers $(6.0$ percent) and presidents or vice presidents (3.6 percent). Other respondents include e.g. supply managers and logistics project leaders. The sample includes smaller, medium-sized as well as larger manufacturing plants, based on number of employees and sales turnover; see Table 1. The sample includes manufacturers of industrial goods ( 86.9 percent), consumer goods ( 10.7 percent) and both types (2.4 percent). All types of customer order decoupling point position are included in the sample; engineer-toorder, make-to-order, assemble-to-order, make-to-stock, and finally make and distribute to stock. The last position refers to holding finished goods inventory in the distribution system, beyond the plant inventory. All these characteristics suggest that the responding firms in the sample are a good representation of the population. 
Table 1. Firm characteristics.

\begin{tabular}{lc}
\hline Characteristic & Distribution \\
\hline Number of employees: & \\
-99 & $10.7 \%$ \\
$100-199$ & $17.9 \%$ \\
$200-499$ & $32.1 \%$ \\
$500-999$ & $14.3 \%$ \\
$1000-$ & $24.0 \%$ \\
\hline Sales turnover (MSEK; $1 \epsilon=9.3$ SEK, May 2007): \\
-99 & \\
$100-499$ & $4.0 \%$ \\
$500-999$ & $36.5 \%$ \\
$1000-4999$ & $17.6 \%$ \\
$5000-$ & $32.4 \%$ \\
\hline
\end{tabular}

\section{Survey Results}

The survey results are presented first in terms of market characteristics to describe the manufacturing environment. Then, we present the results concerning plant roles and responsibilities and the reasons for location. Finally, we present the results concerning the design of the supplier network; both internal and external.

\subsection{Market Characteristics}

In the survey market characteristics are presented along two dimensions, geographical distribution and order winning criteria; see e.g. Hill [12]. The geographical distribution was measured by letting the respondents assign share of sales they had in nine different regions. In recent years the Baltic region has attracted attention as a region for internal or external suppliers to Swedish manufacturing firms, i.e. a near-shore low-cost country. Table 2 shows that the major markets for Swedish firms can be found in Europe, including Sweden, and North America. The "weighted average" is an average of all companies with presence. The relative large difference between the overall average and the weighted average in some regions indicates that once a company is establishing itself on a market it is for a substantial share. Taking North America as an example the overall average is $11.2 \%$. However only half of the companies (44 out of 84) have markets in North America and the ones that do, have on average $21.1 \%$ of sales there.

Each respondent rated 13 different competitive priorities on a 7-point Likert scale, ranging from "low importance" to "decisive importance" with respect to the relevance as an order-winning criterion. The results are presented in Table 3. The results reveal that quality comes out as the highest ranking order winner, with both the highest mean and lowest variance, and price can be found surprisingly far down the list. This might be explained by that manufacturing companies in Sweden, with traditionally high labor costs, have to find alternative means of competing, thus 
focusing on quality, product characteristics and delivery precision instead of price. The survey also allowed for other criteria being added, and brand, traceability, and environmentally friendly product all rated as decisive for the companies in question.

Table 2. Geographic distribution of markets.

\begin{tabular}{lccc}
\hline Market & Overall average & Frequency & $\begin{array}{c}\text { Weighted average with } \\
\text { respect to presence }\end{array}$ \\
\hline Sweden & $34.8 \%$ & 74 & $37.1 \%$ \\
Baltic region & $1.1 \%$ & 21 & $4.2 \%$ \\
Other Europe & $37.0 \%$ & 72 & $40.6 \%$ \\
North America & $11.7 \%$ & 44 & $21.1 \%$ \\
India & $0.7 \%$ & 18 & $2.9 \%$ \\
China & $2.7 \%$ & 27 & $7.9 \%$ \\
Other Asia & $7.1 \%$ & 41 & $13.7 \%$ \\
Other & $4.7 \%$ & 36 & $10.3 \%$ \\
\hline Total & $100.0 \%$ & - & - \\
\hline
\end{tabular}

Table 3. Competitive priorities.

\begin{tabular}{lcccc}
\hline Order winning criteria & Mean & Std.dev. & Median & Mode \\
\hline Quality (conformance to specification) & 6.08 & 0.92 & 6 & 6 \\
Product characteristics & 6.00 & 0.98 & 6 & 6 \\
Delivery precision & 5.45 & 1.04 & 6 & 6 \\
Product range & 4.84 & 1.64 & 5 & 6 \\
Volume flexibility & 4.59 & 1.51 & 5 & 6 \\
Delivery speed & 4.54 & 1.36 & 4 & 4 \\
After-sales service & 4.52 & 1.66 & 5 & 6 \\
Price & 4.51 & 1.37 & 4 & 4 \\
Geographical coverage & 4.33 & 1.71 & 5 & 6 \\
Offer a range of logistical solutions & 4.13 & 1.48 & 4 & 4 \\
Design flexibility & 3.89 & 1.40 & 4 & 4 \\
Size of focal company & 3.81 & 1.37 & 4 & 4 \\
Geographical proximity & 3.34 & 1.66 & 3 & 2 \\
\hline
\end{tabular}

\subsection{Plant Characteristics}

The plant itself was the focal point of the survey. We investigated the reasons for location as it is perceived currently, as well as the competence and responsibilities of the plant. These issues are based on the issues discussed in Ferdows [5,6] and Veerecke and van Dierdonck [13]. Ferdows find three primary strategic reasons for the site; access to low-cost production, access to skills and knowledge, and proximity to market. Veerecke and van Dierdonck also consider socio-political reasons and competition. Other typical reasons are proximity to raw materials, transport hubs, and cheap energy, wherefore we included all these issues in our survey. The plant location factors were captured using a 7-point Likert scale ranging from 
"unimportant" to "of the utmost importance" concerning how important the individual factor is for the plant currently. The result is shown in Table 4. The survey allowed for other criteria being added; among these were proximity to the residence of original founders, as well as a combination of history, existing buildings, need for secrecy, and old factories.

Table 4. Reasons for geographical plant location.

\begin{tabular}{lcccc}
\hline Reason for location & Mean & Std.dev. & Median & Mode \\
\hline Proximity to knowledge & 4.09 & 1.92 & 4 & 4 \\
Proximity to transport hubs & 3.67 & 1.63 & 4 & 4 \\
Proximity to market & 3.40 & 1.84 & 3 & 2,4 \\
Sociopolitical climate & 2.95 & 1.61 & 3 & 2 \\
Proximity to cheap labor & 2.80 & 1.45 & 3 & 2 \\
Proximity to cheap energy & 2.67 & 1.52 & 2 & 2 \\
Proximity to raw materials & 2.54 & 1.61 & 2 & 2 \\
Proximity to competition & 1.70 & 0.95 & 1 & 2 \\
\hline
\end{tabular}

We find that proximity to knowledge is the primary reason for the site location. This is in line with expectations, since many firms choose to locate new sites near industrial parks nearby universities. Proximity to transport hubs comes second, which can be motivated by the relative low density of the population in Sweden and long transportation distances. Proximity to markets is the third major reason, which most likely is related to locations near major cities. The other potential reasons for site location are of lesser importance.

The other plant characteristics in the survey were concerned with the competences and responsibilities of the plant. Again, we based the set of issues on Ferdows [5,6] and Veerecke and Van Dierdonck [13]. The plant competencies and responsibilities were captured using a 7-point Likert scale ranging from "no local responsibility" to "full local responsibility". The result is show in Table 5.

Table 5. Competences and responsibilities at the plant.

\begin{tabular}{lcccc}
\hline Area of plant responsibility & Mean & Std.dev. & Median & Mode \\
\hline Production & 6.63 & 1.02 & 7 & 7 \\
Production planning & 6.43 & 1.14 & 7 & 7 \\
Technical maintenance & 6.22 & 1.42 & 7 & 7 \\
Process development & 5.83 & 1.59 & 6 & 7 \\
Logistics & 5.57 & 1.66 & 6 & 7 \\
Introduction of new process technologies & 5.28 & 1.95 & 6 & 7 \\
Sourcing & 5.25 & 2.05 & 6 & 7 \\
Supplier development & 4.67 & 2.14 & 5 & 7 \\
Supply of global markets & 4.41 & 2.49 & 5 & 7 \\
Introduction of new product technologies & 4.30 & 2.37 & 4,5 & 7 \\
Product development & 4.14 & 2.19 & 4 & 7 \\
\hline
\end{tabular}


Overall, plants seem to possess many competences and responsibilities, indicating that plants typically have higher strategic roles, such as "source", "lead", and "contributor", using the typology by Ferdows $[5,6]$. All measures of central tendency indicate that the average plant at least share the responsibility or have full local responsibility concerning all competence areas.

\subsection{Supply Characteristics}

As a final part of the mapping of the manufacturing networks of Swedish manufacturers, the characteristics of the supply are presented. The survey was concerned with both internal and external suppliers, to be able to detect the extent of similarities and differences between them. We checked for geographical distribution and the criteria for choosing suppliers of both types.

The geographical distribution of the supply networks were found to be focused around Europe, including Sweden, and North America; cf. Table 6. The so-called low cost countries have a relatively small proportion of the inbound supply. The "weighted average with respect to presence" is the average share of inbound material from a country for those companies that have suppliers in that particular region. This gives an indication of whether a low average indicates a small number of companies with heavy presence in a region or a large number of companies with small presence.

Table 6. Geographical distribution of internal and external suppliers (all 84 plants have external suppliers, while 45 of these also have internal suppliers).

\begin{tabular}{lcrr|rrr}
\hline $\begin{array}{l}\text { Geographical } \\
\text { distribution of } \\
\text { suppliers }\end{array}$ & $\begin{array}{c}\text { Fre- } \\
\text { quency }\end{array}$ & Average & $\begin{array}{c}\text { Weighted } \\
\text { average wrt } \\
\text { presence }\end{array}$ & $\begin{array}{c}\text { Fre- } \\
\text { quency }\end{array}$ & $\begin{array}{c}\text { Average } \\
\text { Weighted } \\
\text { average wrt } \\
\text { presence }\end{array}$ \\
\hline Sweden & 32 & $48.1 \%$ & $67.6 \%$ & 73 & $55.7 \%$ & $57.2 \%$ \\
Baltic Region & 4 & $3.7 \%$ & $42.0 \%$ & 23 & $2.0 \%$ & $6.6 \%$ \\
Other Europe & 28 & $37.4 \%$ & $60.0 \%$ & 68 & $29.1 \%$ & $32.1 \%$ \\
North America & 10 & $7.5 \%$ & $33.9 \%$ & 30 & $4.7 \%$ & $11.8 \%$ \\
India & 4 & $1.5 \%$ & $17.3 \%$ & 27 & $4.2 \%$ & $11.7 \%$ \\
China & 1 & $0.0 \%$ & $2.0 \%$ & 12 & $0.5 \%$ & $3.4 \%$ \\
Other Asia & 2 & $0.5 \%$ & $11.0 \%$ & 19 & $2.1 \%$ & $8.1 \%$ \\
Other & 2 & $1.2 \%$ & $26.5 \%$ & 13 & $1.8 \%$ & $10.5 \%$ \\
\hline Total & - & $100.0 \%$ & - & - & $100.0 \%$ & - \\
\hline
\end{tabular}

Perhaps more interesting is the criteria on which suppliers are selected. The respondents were asked to rate the importance of 15 different criteria for choosing suppliers, using a 7-point Likert scale, ranging from "low importance" to "deciding importance". The result is presented in Table 7. Two clear conclusions can be drawn from the comparison between internal and external supplier selection. First the decision to use an internal supplier is based on very few criteria (as opposed to the selection of external suppliers); many criteria has received either a very high (7) or a very low score (1). Second, there is a significant difference in how internal and 
external suppliers are selected. "Corporate decision" is used significantly higher for internal suppliers, while all other criteria rank higher for selecting external suppliers. This indicates that the choice of an internal supplier is to a large extent based on a single corporate decision, reflecting competence, quality, control and synchronization. Many of the other issues are even significantly more important in the choice of external supplier, indicating a multi-criteria decision process. Here, quality, price and delivery dependability are the top three criteria; all significant at the 0.01 level. A paired $t$-test was used for testing the differences between criteria for selecting internal and external suppliers, for the 45 companies that has both internal and external suppliers.

Table 7. Criteria for selecting internal and external suppliers ("control and synchronization" was not available as an answer for the section on external suppliers").

\begin{tabular}{|c|c|c|c|c|c|c|c|c|}
\hline \multirow{2}{*}{ Criteria } & \multicolumn{4}{|c|}{ Internal } & \multicolumn{4}{|c|}{ External } \\
\hline & Mean & Std.dev. & Med. & Mode & Mean & Std.dev. & Med. & Mode \\
\hline Corporate decision*** & 5.72 & $1 . \overline{74}$ & 6 & 7 & 4.02 & 1.99 & 4 & 4 \\
\hline $\begin{array}{l}\text { Exploit/use/keep } \\
\text { important competence }\end{array}$ & 4.51 & 2.28 & 5 & $1,6,7$ & 4.67 & 1.54 & 5 & 6 \\
\hline $\begin{array}{l}\text { Quality (conformance } \\
\text { to specification) } * * *\end{array}$ & 4.49 & 2.21 & 5 & 6 & 6.01 & 1.02 & 6 & 6 \\
\hline $\begin{array}{l}\text { Control and } \\
\text { synchronization }\end{array}$ & 4.17 & 2.11 & 4 & 6 & - & - & - & - \\
\hline $\begin{array}{l}\text { Delivery } \\
\text { dependability } * * *\end{array}$ & 4.07 & 2.09 & 4 & 1 & 5.33 & 1.25 & 6 & 6 \\
\hline Volume flexibility*** & 3.87 & 1.92 & 4 & 5 & 4.59 & 1.39 & 5 & 4 \\
\hline Price ${ }^{* * *}$ & 3.72 & 2.08 & 4 & 1 & 5.49 & 1.14 & 6 & 6 \\
\hline Delivery speed* & 3.60 & 1.91 & 4 & 1 & 4.28 & 1.48 & 4 & 4 \\
\hline Design flexibility & 3.37 & 2.00 & 3,5 & 1 & 3.77 & 1.66 & 4 & 4 \\
\hline Product range & 3.15 & 1.91 & 3 & 1 & 3.48 & 1.46 & 4 & 4 \\
\hline $\begin{array}{l}\text { Geographical } \\
\text { proximity** }\end{array}$ & 3.11 & 2.03 & 2 & 1 & 3.31 & 1.56 & 3 & 5 \\
\hline Logistical solution*** & 2.78 & 1.75 & 2 & 1 & 3.85 & 1.70 & 4 & 4 \\
\hline Size of company*** & 2.74 & 1.74 & 2 & 1 & 3.90 & 1.37 & 4 & 4 \\
\hline $\begin{array}{l}\text { Geographical } \\
\text { coverage }\end{array}$ & 2.57 & 1.87 & 2 & 1 & 3.19 & 1.65 & 3 & 2 \\
\hline After-sales service** & 2.42 & 1.67 & 2 & 1 & 3.27 & 1.75 & 3 & 2 \\
\hline
\end{tabular}

*** Difference between internal and external suppliers is significant at the 0.01 level;

** Significant at the 0.05 level; * Significant at the 0.10 level.

\section{Discussion and Concluding Remarks}

In this paper we have investigated how manufacturing networks are designed, related to the market and product characteristics, the distribution and roles of plants, and the selection of internal and external suppliers, based on a survey of 84 Swedish manufacturing plants. The role of quality and price is interesting. Quality is perceived as a high priority for competing in the market, for plant location and roles, 
and for both internal and external suppliers. Thus, there is a strong alignment concerning quality. As for price, the products do not compete on price in the market, the plants do not have a low-cost focus, but cost is an important issue for choosing external suppliers. Thus, this supports the role of cost as a major issue for outsourcing parts of the manufacturing network, that concern items for which cost is important.

The most important lesson to be learned for managers from this research is that companies have a differentiated treatment of internal and external suppliers. Internal suppliers are primarily chosen for quality, competence, control and synchronization related to a corporate decision, while external suppliers have to compete on quality, competence, price and delivery as well as many other issues. Even though this study focuses on Swedish manufacturing networks, the results are most likely representative of many western countries. The design of the manufacturing network including the external suppliers has to be aligned to the market characteristics and take the particular products into consideration.

\section{References}

1. I. Colotla, Y. Shi and M. J. Gregory, Operation and performance of international manufacturing networks, International Journal of Operations \& Production Management, 23(10), 1184-1206 (2003).

2. Y. Shi and M. Gregory, International manufacturing networks - to develop global competitive capabilities, Journal of Operations Management, 16(2,3), 195-214 (1998).

3. M. Rudberg and J. Olhager, Manufacturing networks and supply chains: an operations strategy perspective, Omega - The International Journal of Management Science, 31(1), 29-39 (2003).

4. F.L. DuBois, B. Toyne and M.D. Oliff, International manufacturing strategies of U.S. multinationals: a conceptual framework based on a four-industry study, Journal of International Business Studies, 24(2), 307-333 (1993).

5. K. Ferdows, Mapping international factory networks, in: Managing International Manufacturing, edited by K. Ferdows (Elsevier Science Publishers B.V, North-Holland, New York, 1989), pp. 3-21.

6. K. Ferdows, Making the most of foreign factories, Harvard Business Review, 75(2), 73-88 (1997).

7. C.S. Gailbraith, Transferring core manufacturing technologies in high-technology firms, California Management Review, 32(4), 56-70 (1990).

8. M.T. Flaherty, Global Operations Management (McGraw-Hill, New York, NY, 1996).

9. M.E. Porter (Ed.) Competition in Global Industries (Boston: HBS Press, 1986).

10.D.A. Dillman, Mail and Internet Surveys: The Tailored Design Method (John Wiley \& Sons Inc., New York, 2000).

11.C. Forza, Survey research in operations management, International Journal of Operations and Production Management, 22(2), 152-194 (2002).

12.T. Hill, Mamufacturing Strategy (Palgrave, New York, 2000)

13. A. Vereecke and R. van Dierdonck, The strategic role of the plant: testing Ferdow's model, International Journal of Operations \& Production Management, 22(5), $492-514$ (2002). 